\title{
Fine structure of Henneguya amazonica (Myxozoa) in ovarian follicles of Hoplosternum littorale (Teleostei) from the Amazon river
}

\author{
A. Torres ${ }^{1}$, E. Matos ${ }^{2}$, C. Azevedo ${ }^{1, *}$ \\ 'Department of Cell Biology, Institute of Biomedical Sciences and IMAR-Institute of Marine Research, University of Oporto, \\ P-4000 Porto, Portugal \\ ${ }^{2}$ Center of Biological Sciences, Federal University of Pará, 66000 Belém, Brazil
}

\begin{abstract}
During an ultrastructural study of oogenesis in the Amazonian teleost fish Hoplosternum Littorale we observed Henneguya amazonica Rocha, Matos \& Azevedo, 1992 (Myxosporea) inside the follicles and ovarian stroma. The presence of myxosporeans in sexual tissues of teleosts is rather unusual and has previously been described only for this group of fishes. The parasite forms cysts between the zona pellucida and follicle cells of the oocytes. Inside these cysts we found early phases of sporogenesis. In the ovarian stroma we only found mature spores and no cysts were seen. In this paper we present an ultrastructural description of the early sporogenic phases of the parasite. The possible infection cycle and implications for the reproductive potential are briefly discussed.
\end{abstract}

KEY WORDS: Ultrastructure - Parasite - Myxozoa $\cdot$ Henneguya amazonica - Ovarian follicle - Teleost

\section{INTRODUCTION}

Since the first description of Henneguya in 1892 by Thélohan (Lom \& Noble 1984), many species of the genus have been reported as parasitizing both fresh and salt water fish (Jakowska \& Nigrelli 1953, Minchew 1977, Shariff 1982, Haldar et al. 1983, Kent \& Hoffman 1984, Haldar \& Mukherjee 1985, Landsberg 1987, Azevedo \& Matos 1989). The localization of the Henneguya spp. in the host is most variable, parasitizing a wide range of organs and tissues: gills, branchial cavities, gallbladder, urinary ducts, intestine, muscles, kidney, heart (Jakowska \& Nigrelli 1953, Haldar \& Mukherjee 1985) and brain (Kent \& Hoffman 1984). Based on the infection site of Henneguya, Minchew (1972) divided the infections into the following 'working types': interlamellar, intracapillary, visceral and cutaneous. According to some authors these parasites cause several pathogenic manifestations in their hosts (Jakowska \& Nigrelli 1953, Current \& Janovy 1976 ,

\footnotetext{
- Addressee for correspondence
}

Lom 1987, Azevedo \& Matos 1989). According to others, they have no apparent pathogenicity, at least in some cases (Haldar et al. 1983, Sarkar et al. 1985).

Despite the renewed interest in this group of fishes, the Amazonian representatives have been subject to very few ultrastructural studies (Azevedo \& Matos 1989). In this paper we report some ultrastructural aspects of the recently described species Henneguya amazonica Rocha, Matos \& Azevedo, 1992, namely the first sporogenic stages present on ovarian stroma and follicles of the Amazonian teleost Hoplosternum littorale.

\section{MATERIALS AND METHODS}

The specimens of freshwater teleost fish Hoplosternum littorale Hancock, 1928 used in this study were collected during March to May 1993 from the lower Amazon river near Belém, Brazil.

Small pieces of ovary and isolated oocytes were fixed with $3 \%$ glutaraldehyde in $0.2 \mathrm{M}$ cacodylate buffer $\left(\mathrm{pH} \mathrm{7.4)}\right.$ for $3 \mathrm{~h}$ at $4{ }^{\circ} \mathrm{C}$, washed in the same buffer for $2 \mathrm{~h}$ at $4{ }^{\circ} \mathrm{C}$ and then post-fixed in $2 \%$ osmium tetroxide 


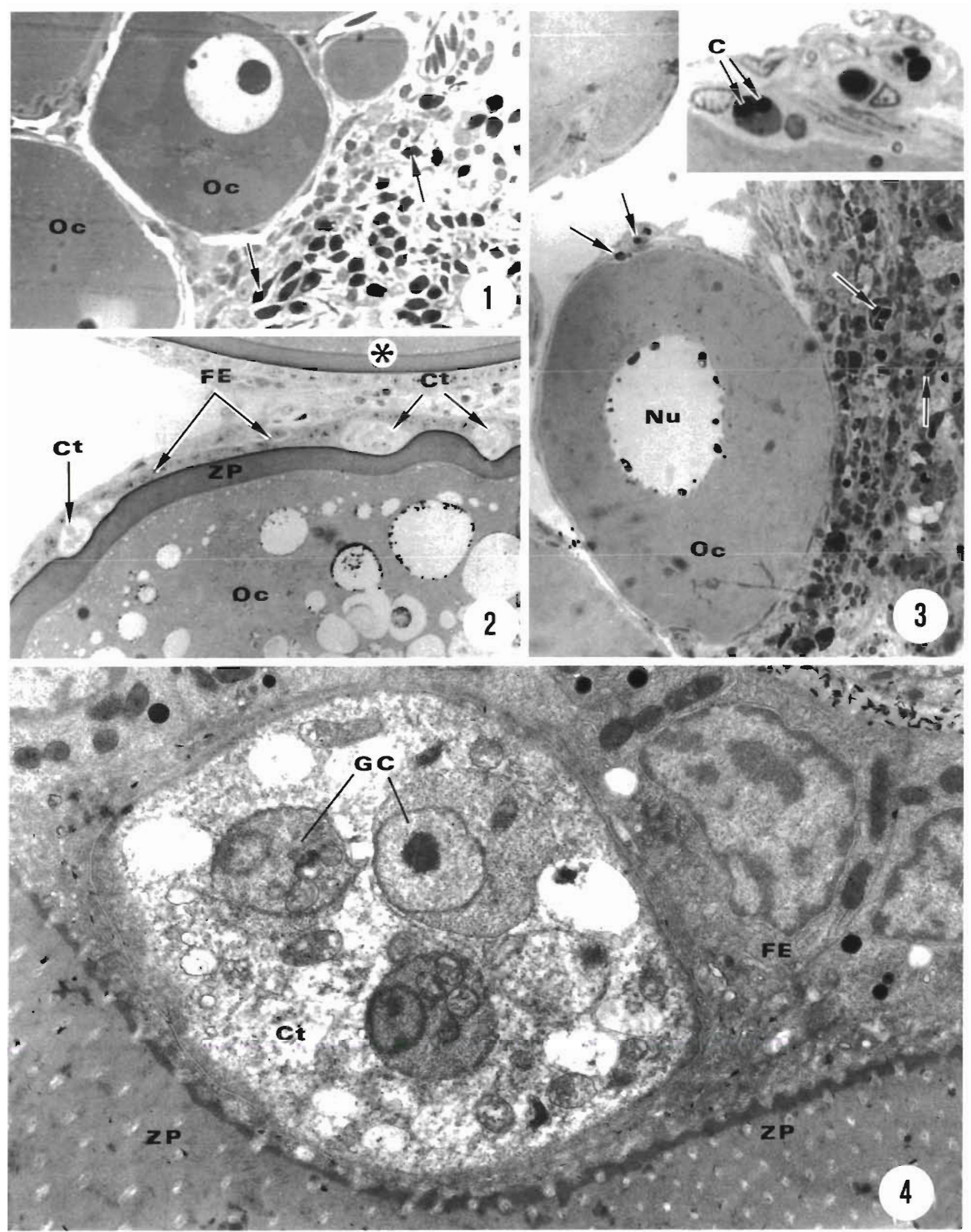


Figs. 1 to 4. Henneguya amazonica parasitizing Hoplosternum littorale. Fig. 1. Semithin section of the ovary with young oocytes (Oc) and ovarian stroma, with parasites (arrows), (LM $\times 890)$. Fig. 2. Semithin section of a parasitized oocyte (Oc) and the periphery of a nonparasitized one (*). Cysts (Ct) lie between the zona pellucida (ZP) and the follicular epithelıum (FE). The zona pellucida underlying the cysts is depressed. (LM, × 750) Fig. 3. Semithin section of parasitized ovarian stroma and follicle (arrows). The parasites of the follicles lie between the oocyte membrane and the follicular epithelium (LM; $\times 620)$ Inset. the 2 capsules (C) of the parasite are visible. Nu: nucleus, Oc oocyte: (LM, $\times 1700)$. Fig. 4. Ultrathn section of a cyst (Ct) in a similar region as Fig. 2, containing some young stages of the generative cells (GC), situated between the zone pellucida ( $\mathrm{ZP}$ ) and follicular epithelium (FE) of the oocyte $($ TEM $\times 10800)$

in the same buffer for 2 h at $4^{\circ} \mathrm{C}$. Ethanol and propylene oxide dehydration were followed by embedding in Epon. Semithin sections were cut for light microscopy (LM), and stained with methylene blue-Azur Il to locate the parasites. Ultrathin sections were stanned with uranyl acetate and lead citrate and observed in a JEOL 100CXII transmission electron microscope (TEM) operated at $60 \mathrm{kV}$.

\section{RESULTS}

In ovary sections of infected specimens of Hoplosternum littorale, we found mature spores and early sporogenic phases of Henneguya amazonica. The spores of the parasite were found either in the ovarian stroma or lying between the zona pellucida and the follicular epithelıum of the oocytes (Figs. 1 to 3). The early sporogenic phases were found inside cysts located between the zona pellucida and follicular epithelium of the oocytes (Figs. $2 \& 4$ ). The zona pelluclda region underlying the cysts was depressed, a feature that was not observed in the nonparasitized region or oocytes (Fig. 2). The cysts presented a conspicuous wall with protrusions at both sides. Inside them the sporogenous phases could be seen (Figs. 4 to 6 ). The generative cells have a double membrane, and a poor cytoplasm which contains some mitochondria, a small amount of rough endoplasmic reticulum (RER), and in some cases an eccentric urregular nucleus. The nucleus had a compact
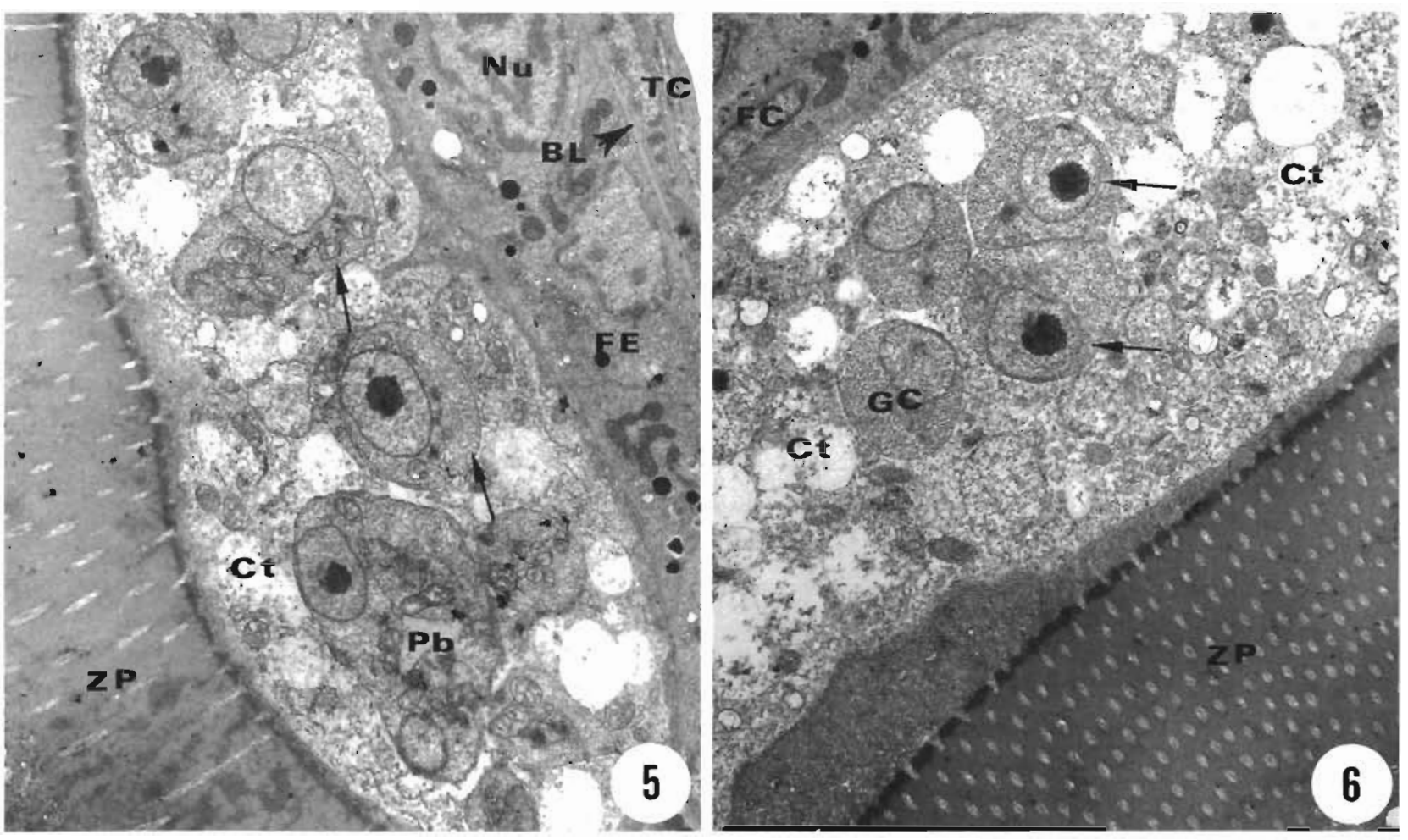

Figs. 5 \& 6. Henneguya amazonica parasıtızıng Hoplosternum httorale. Fig. 5. Ultrathin section of a follucle cyst lyng between the zona pellucida (ZP) and follicular epithelium (FE). Inside the cyst several young stages of sporogenesis are visıble (arrows) There is a young pansporoblast $(\mathrm{Pb})$. TC: teca cell, BL. basal lamina; Nu- nucleus; Ct. cyst. $(\mathrm{TEM} ; \times 5600)$. Fig. 6 . Ultrathin section of the cyst showing epithelial cell dispersed among generatıve cells ( $\mathrm{GC}$ ) and 2 generatuve cells jouned together (arrows). This late stage may represent the initial stage of pansporoblast formation $\mathrm{FC}$ follıcle cell; Ct cyst; ZP zona pellucida, (TEM. $\times 5600)$ 
nucleolus (Figs. 5 \& 6). Some of these cells had cytoplasmic microtubules. Some cells lying side by side were also observed. This disposition seems to represent the first stage of sporogenesis (Figs. $5 \& 6$ ). There were no significant features that could be observed to distinguish one cell from the other.

No vegetative nuclei were seen inside the cysts, but several organelles, such as mitochondria, Golgi complexes and RER were present amidst the sporogenic cells.

\section{DISCUSSION}

The morphology of fully mature spores is consistent with previous descrintions of the genus Henneguya (Lom \& Noble 1984) and this is probably the same species previously described (Azevedo \& Matos 1989). Present results compare well with recent ultrastructural data obtained for $H$. amazonica (Rocha et al. 1992) and may confirm that this parasite shows similar organization and consequently may be considered as belonging to the same species.

Our observations led to the suggestion that this species follows the 'conventional idea of a Myxosporean life cycle' as defined by Lom (1987).

The presence of Myxosporea in sexual tissues of teleost fish is an unusual situation judging by the scarce amount of information available on the subject. The studies by Walliker (1969) on testis of Lepidosiren paradoxa and Paperna (1973) on ovary of Haplochromis angustrifons are the only recent references available. Neither of these papers deals with ultrastructural aspects.

This unusual presence in sexual tissues is not exclusive to Myxosporea, since it has also been reported for Microsporea (Summerfelt \& Warner 1970, Dykova \& Lom 1980).

In our case, the presence of the parasite seemed restricted to the follicle and ovarian stroma, contrary to the situation for Myxobolus ovariae which invades the mature egg (Paperna 1973). Despite the massive infections of the ovarian stroma, the number of infected follicles was small. The sporogenic stages of development in the follicles took place inside a cyst wall, and this might account for the restriction of the infection to this particular region of the oocyte, leaving its interior free from parasites.

The morphology of infected oocytes is not significantly affected so there is a possibility that they may proceed with normal development and survive hatching. They may well be fertilized and the infection transmitted to the next generation as happens in some Microsporea (Summerfelt \& Warner 1970), however the possibility of destruction of the ovary cannot be discarded.
Acknowledgements. This work was partially supported by 'Science Programme' for EEC (Contract no. 0115/G/92) and CNPq-Brazil.

\section{LITERATURE CITED}

Azevedo, C., Matos, E. (1989). Some ultrastructural data on the spore development in a Henneguya sp., parasite of the gill of a Brazilian fish. Parasitol. Res. 76: 131-134

Current, W. L., Janovy, J. (1976). Ultrastucture of inter lamellar Henneguya exilis in the channel catfish. J. Parasitol. 62: $975-981$

Dyková, I., Lom, J. (1980). Tissue reactions to microsporidian infections in fish. J. Fish Dis. 3: 265-283

Haldar, D. P., Das, M. K., Sharma, B. K. (1983). Studies on Protozoan parasites from fishes. Four new species of the genera Henneguya Thélohan, 1892, Thelohanellus Kudo, 1933, and Myxobolus Butschli, 1892. Arch. Protistenkd. 127: $283-296$

Haldar, D. P., Mukherjee, M. (1985), Studies on Bivalvulidae (Myxozoa: Myxosporea): observations on two new species of Henneguya from food fishes of West Bengal, India. Arch. Protistenkd. 130: 419-425

Jakowska, S., Nigrelli, R. F. (1953). The pathology of Myxosporidiosis in the electric eel, Electrophorus electricus (Linnaeus), caused by Henneguya visceralis and $H$. electrica spp. nov. Zoologica 38: 183-191

Kent, M. L., Hoffman, G. (1984). Two new species of Myxozoa, Myxobolus inaequus sp. $\mathrm{n}$. and Henneguya theca sp. n. from the brain of South American knife fish, Eigemannia virescens (V). J. Protozool. 31: 91-94

Landsberg, J. H. (1987). Myxosporean parasites of the catfish, Clarias lazera (Valenciennes). Syst. Parasitol. 9: 73-81

Lom, J. (1987). Myxosporea: a new look at long-known parasites of fish. Parasitol. Today 3: 327-332

Lom, J., Noble, E. R. (1984). Revised classification of the Class Myxosporea Bütschli, 1881. Folia Parasitol. (Prague) 31: 193-205

Minchew, C. D. (1972). Identification and frequency of occurrence of four forms of Henneguya found in channel catfish. Proc. A. Conf. Southeast. Ass. Game Fish Comm. 26: $336-340$

Minchew, C. D. (1977). Five new species of Henneguya (Protozoa: Myxosporida) from Ictalurid fishes. J. Protozool. 24: $213-220$

Paperna, I. (1973). Occurrence of Cnidospora infections in freshwater fishes in Africa. Bull. Inst. fr. Afr. noire 35: 509-521

Rocha, E., Matos, E., Azevedo, C. (1992). Henneguya amazonica n. sp. (Myxozoa, Myxobolidae), parasitizing the gills of Crenicichla lepidota Heckel, 1840 (Teleostei, Cichlidae) from Amazon River. Eur. J. Protistol. 28: 273-278

Sarkar, N. K., Mazumder, S. K., Pramanik, A. (1985). Observations on four new species of myxosporidia (Myxozoa) from channid (Ophicephalida) fishes of West Bengal, India. Arch. Protistenkd. 130: 289-296

Shariff, M. (1982). Henneguya shaharini sp. nov. (Protozoa: Myxozoa), a parasite of marble goby, Oxyelotris marmoratus (Bleeker). J. Fish Dis. 5: 37-45

Summerfelt, R. C., Warner, M. (1970). Incidence and intensity of infection of Plistophora ovariae, a microsporidian parasite of the golden shiner, Notemigonus crysoleucas. In: Snieszko, S. F. (ed.) A Symposium on Diseases of Fishes and Shellfishes. Special Publ. no. 5. American Fisheries Society, Washington, DC, p. 142-160

Walliker, D. (1969). Myxosporidea of Brazilian freshwater fishes. J. Parasitol. 55: 942-948 